\title{
Research on the Red Culture and the Localization of Marxism in China
}

\author{
Xin Dong \\ Zhuhai College of Jilin University \\ Zhuhai, China 519041
}

\begin{abstract}
Where there are people there is culture. Cultural thoughts with eternal vitality are the foundation for the survival of the masses and the power-holders in dynasties. This is why the Confucian culture of China can dominate the thoughts of people for thousands of years. The culture does not have emotional tendency. The prominence of it depends on the rationality of its survival and the approval of people. In the long history, the people at different periods have different judgments on the same culture. The culture that meets the needs of development of times will be accepted. The unsuitable culture will be altered, developed or abandoned by people. Only those parts with the truth will extend the life. With the continuous development of the society, new theoretical systems appear in succession. In the mid-nineteenth century, the Marxism emerged. It provides the new thoughts for people to explore the forms of regime. After bringing in the guiding thought of the Marxism, we have established the People's Republic of China and have created the unique red culture. The red culture combines with the practice in China and absorbs the essence of the Marxist theory, referring to the wisdom crystallization of Chinese people.
\end{abstract}

\section{Keywords—red culture; Marxism; localization in China}

\section{INTRODUCTION}

Nowadays, the international competition is increasingly fierce with the economic globalization. To gain a firm foothold, our country must strengthen the construction of the cultural soft power. It means reaching the cultural consensus among the masses and establishing the common spiritual belief and national concept of honor and disgrace. Our country is the red political power established under the leadership of the Communist Party of China and defends the regime of the people's democratic dictatorship. Since the establishment of the People's Republic of China, the construction of the red political power grows vigorously. The red symbolizes socialism and revolution. The red culture is the cultural essence of the Communist Party of China, and records the history of struggle of China. With the soaring development of the Chinese society, the red culture is endowed with the meanings of the new era. The red culture will be the result of the Marxism localization, as well as the practical activity that the Chinese people creatively absorb

Fund project: Key project in innovation of moral education in colleges of Guangdong Province in 2015, the Moral Education Model with Collaboration between the Army and the School under the Guidance of "China Dream", (Project No.: 2015DYZD029). the excellent foreign cultures. Its enrichment and development will continuously provide nourishment for the career of China.

\section{THE UNDERSTANDING OF THE RED CULTURE}

The red has special meaning in our country. It is the symbol of happy atmosphere and the pronoun of the justice and the glory. The red represents the blood of soldiers and the persevering spirit. Since the founding of the People's Republic of China, we have implemented such activities as social production and transformation under the influence of the red culture. The national flag of our country is called the Five-starred Red Flag; the films with the theme of war are called the red films with revolutionary theme; the revolutionary base area related to the anti-Japanese war and the old sites are developed into the red scenic spots; the advanced persons and groups of various industries are granted with the big red flowers in the commendation meetings. The red culture has been not only the advanced political guiding thought but also an inseparable part of our daily life. In order to achieve the goal of the communist society, it vigorously carries forward the traditional virtues such as the patriotism and the hard work and plain living and provides power for the progress of the people. China is the fertile soil for the growth of the Marxist theory. At the meantime, it provides adequate nourishment for the appearance and the development of theories such as the Mao Zedong thought and the Deng Xiaoping Theory, the three represents theory and the Scientific Outlook on Development, indicating directions for the construction of socialism with Chinese characteristics.

\section{THE UNDERSTANDING OF THE MARXISM AND THE LOCALIZATION OF IT IN CHINA}

The Marxist theoretical system includes two parts, namely the scientific socialism and the materialism. The scientific socialism is divided into economy and politics. The economy researches the principle of interaction among product elements, productivity and productive relations, and the development law of the market economy; the politics mainly research the political system of a country. The materialism is the essence of the Marxist theory. It proposes the origin of the world is matter, proceeding from reality in everything one does and things continuously develop and make progress in twists and turns. The Marxist theory 
scientifically analyzes and explains all aspects of the society and reveals the development tendency of the society at the same time improves the ability of people in understanding and transforming the world. The localization of Marxism in China means adding the Chinese elements to the original theoretical system according to the situation of China in the process of the Socialist Transformation, in order to make it better meet the demands of the development of China. The localization of Marxism in China is the result of the development of times. It promotes the formation of the theoretical system with Chinese characteristics and plays a vital role in the establishment stage and the development stage of the People's Republic of China. Besides, it will present more affluent contents with the development of China.

\section{THE DEVELOPMENT AND THE INTEGRATION OF THE RED CULTURE AND THE LOCALIZATION OF MARXISM IN CHINA}

\section{A. The Preliminary Development Stage of the Red Culture and the Localization of Marxism in China}

Under the dual oppression of imperialism and feudalism, China was caught in the situation with domestic strife and foreign aggression. In the process of condemning the feudal forces that seek power and wealth by betraying our country, the May 4th Movement broke out. It declares the proletariat comes onto the historical stage of our country. The victory of the October Revolution extensively spreads the MarxismLeninism worldwide. Our country also realizes the reliability of the Marxism thought and shouts the slogan of constructing the socialist country. The socialism becomes the hot issue among people. Because of the complicated social situation, not all people accept the Marxist theory. The works related to the socialism during this period emerge in endlessly, but fail to reach a consensus on the socialist system. The red culture rises in response to the proper time and conditions under this environment. Li Dazhao and Chen Duxiu, the leaders of the great proletarian struggle, become the founders of the red culture. The publication of chapters such as Where the Justice Is and the Victory of the Bolshevism causes the profound social response. The masses are enthusiastic about learning the Marxist-Leninist thought. The red culture takes the initial shape.

\section{B. The Rapid Development of the Red Culture and the Localization of Marxism in China}

In the year 1921, the Communist Party of China formally established. It is the first proletarian party of our country. Besides, it takes the Marxism-Leninism as the guiding thought and opens the development stage of the red culture. In order to strive for the victory of the national independent movement, the revolutionary struggle under the leadership of the Communist Party of China begins. At the initial period of founding the political party, all the members of the Communist Party receive the education of the guiding thought. All party members must follow the MarxismLeninism and establish the democratic regime of the people. Afterwards, the revolutionary situation is urgent, and the
Anti-Japanese War breaks out. The red culture develops rapidly in the revolutionary base area. Because of the misguidance of the left-leaning guiding thought in the party, under the encirclement and the suppression of Kuo Min Tang, the Red Army begins the Long March of 25,000 Li and passes the snow mountain and the grassland. The revolutionists with amazing will win victory in this struggle and transfer the main force of our army. The red culture firms the confidence of the revolutionists in the struggle. The revolutionary leaders learn a lesson from the failure of campaigning against "encirclement and suppression", carefully research the Marxism and hold Zunyi Meeting. It proposes on the meeting that Chinese revolution must be connected with the reality of our country and flexibly use the Marx's guiding thought. The proposition indicates directions for the revolutionary struggles of China. They change the operational policy, which is the start of the localization of Marxism in China. Later, the Communist Party of China pays attention to the interests of the whole and unifies the revolutionary battlefront, and finally wins the revolutionary victory through depending on the forces of the masses. In the lengthy anti-Japanese activities, the red culture is enriched and developed and becomes the spiritual pillar of the revolutionary soldiers who do not fear hardships and dangers. At the meantime, it becomes famous for the revolutionary spirit of soldiers who face death unflinchingly, and become the example for the younger generations to learn and the wheels of progress. After the establishment of the People's Republic of China, people continue to carry forward the influence of the red culture and vigorously implement the Socialist Transformation. They have created tremendous remarkable achievements and have changed the post-war appearance at short notice.

\section{The High Integration of the Red Culture and the Localization of Marxism in China}

The red culture and the localization of Marxism in China continuously change with the social development. They integrate with each other and show different appearances. The localization of Marxism in China is the source of the red culture and determines the emotional tendency of the red culture in different periods. During the War of Resistance against Japan, the people follow the examples of combat heroes such as Huang Jiguang and Qiu Shaoyun. At the early years of new China, the people follow the examples of Lei Feng and Wang Jinxi. In modern times, we compliment common heroes such as "the young man who rescues the girl through lifting her" and "the young person seizing the knife to rescue people". The process of bringing the MarxismLeninism theory in our country is full of twists and turns and very long. The influence of the red culture on the value orientation of people has obvious epochal character. After the establishment of the People's Republic of China, under the guidance of the Marxism, we implement the producing activities of socialism and have made great progress; in the process of the Socialist Transformation, because we mechanically imitate the Soviet pattern, it appears the comprehending deviation of the Marxism. It leads to the Great Cultural Revolution, which brings heavy losses for our party; after the ten years of the Great Cultural Revolution, it 
saps the vitality of our country. In the face of the new problems on the road of social construction, the leading group led by Deng Xiaoping envisages the errors in the leadership of the party and actively summarizes the historical lessons. On the basis of thoroughly analyzing the Marxism, they propose the great strategy of the reform and opening-up policy and design the blueprint of the Socialist Modernization and shout the slogan of establishing the socialism with Chinese characteristics. It is another pioneering work of the localization of Marxism in China. The service objects of the red culture and the localization of Marxism in China are the laborers. It is summarized from the practice of people and will serve the masses. The core of the Marxist theory is to insist the people are the creators of the world, and the orientation of all decisions is to create more benefits for people. Our country highly affirms the proposition of the Marxism on people's status, implements the system of people's congress. We adhere to the governing idea of clean governance and serving the people, regard the masses as the master of our country. The red culture under the leadership of the Communist Party is the regime of people. In the modernization construction, we keep on developing the Marxist-Leninist thought and establish the Scientific Outlook on Development and propose revitalizing the country through science and technology, in order to build the harmonious socialist society and promote the development of the red culture and the localization of Marxism in China.

\section{THE INTERACTION BETWEEN THE RED CULTURE AND THE LOCALIZATION OF MARXISM IN CHINA}

\section{A. The Influence of the Localization of Marxism in China on the Red Culture}

The localization of Marxism in China is the historical background of emergence and development of the red culture, laying the spiritual foundation for the emergence of the numerous red cultures. In time of war, Mao Zedong creatively absorbs the Marxist theory and formulates a series of struggle tactics, in order to guide people to implement armed struggle through correct battle models. They finish the Long March of 25,000 $\mathrm{Li}$ and establish base areas in enemy's rear areas and the revolutionary united front. At the meantime, they establish the steel-like discipline and the high spirit among the revolutionists and open the precedent of the development of the red culture. With the continuous improvement of the Marxism, the degree of its localization in China also deepens gradually. In the period of the modernization construction, social politics, economy, culture and diplomacy are inseparable from the guidance of the Marxist theory. The function of the red culture in the social construction highlights increasingly. At the present stage, the embodiment of epochal character of the red culture in the construction of a harmonious society is the result of the localization of Marxism in China.

\section{B. The Effect of the Red Culture in Promoting the Localization of Marxism in China}

The red culture is the carrier to transmit the Marxism and is the concrete form to publicize the Marxist thought among the masses. We must integrate the traditional Chinese culture with the Marxist theory and deepen people's understanding of it to reduce the drag of transmitting the Marxist theory among people and accelerate the speed of people in accepting it. For example, when we tell the idea that "things are the unity of contradictions", we do not need to transmit concepts such as the universality of contradictions and the analytical method of primary and secondary contradictions to the masses. We only need to guide people to tease and understand the situation of social development. Our country is still and will be in the primary stage of socialism for a long time. Although the problems still exist in the socialist construction, the unreasonable aspects will not influence the development direction and progress of the society. At the present stage, the primary task is to implement the social and economic construction and to meet the increasing material and cultural needs of people. After thoroughly understanding the leadership thought of the Communist Party, they will be full of confidence and support the modernization construction of China.

\section{The Red Culture and the Localization of Marxism in China Jointly Promote the Social Progress}

The red culture and the localization of Marxism in China supplement each other and have mutual effect. The red culture lays the spiritual foundation for the development of the Marxist theory in China and deepens the understanding and acceptance of people about the foreign culture. It is the most extensive invisible theoretical education for people. The red culture and the localization of Marxism in China jointly award the historical and heavy task to the Communist Party in leading the people of all ethnic groups to entirely realize a moderately prosperous society. They are the internal driving force to build a harmonious society, promote social and cultural prosperity and build the socialist system. Since the reform and the opening-up, the Chinese society has had earthshaking changes. We adhere to carrying forward the spirit of the red culture and continuously deepen the degree of the localization of Marxism in China. At the same time, we improve the socialist system and develop the market economy, fundamentally emancipate and develop the productive forces. Although the development forms change greatly, the influences of the red culture and the localization of Marxism in China do not reduce. For example, we insist the mastership position of people all the time. In the modern society, we pay more attention to the construction of democracy and civil rights; vigorously develop economy and culture and meet people's increasing material and cultural needs; introduce the policy of benefiting people and furthest protect the rights of people; intensify the input in the science and education cause to cultivate more compound talents; open more projects related to the research and development of high-tech products to improve our international competitiveness. We adhere to the working attitudes of bearing hardships and standing hard work and coming down 
to earth in the modernization construction all the time and have greatly improved the comprehensive national power.

\section{CONCLUSION}

The culture is the productivity spiritually and the important component of comprehensive strength of a national. It provides technical support for the update and the progress of science and technology as well as the products. Increasing numbers of countries devote to its development and research. The culture is also the means for countries to assemble wealth and contains huge economic value. At the meantime, the culture provides the powerful support for the improvement of the military force and increases the safety factor of the national defense. The nearly two hundred years of social practice proves the Marx's theory tremendously promotes the social progress. Besides, it has great vitality. The red culture promotes the localization of Marxism in China and refers to the foundation that guarantees the smooth economic construction of Socialism with Chinese characteristics. The social practice also proves people begin the new period of the happy life under the guidance of theoretical system of the materialism of Marx. We must make the best of the interaction between the red culture and the localization of Marxism in China and promote the round and sound development of China. The red culture is the unique culture of China. It becomes the political value orientation of Chinese citizens. They establish the correct outlook on life and the world outlook advocate the leadership of the Communist Party of China and protect interests of the masses, at the meantime make contributions to the establishment of the stable socialist country.

\section{REFERENCES}

[1] Wang Yong. The Red Culture and the Localization of Marxism in China, in the Era and among the Masses [J], Journal of Guizhou Normal University (Social Science Edition), 2011, (5): 89-90

[2] Yan Ming. Analysis on the Promotion of the Localization of Marxism in China on the Development of the Red Culture [J], Fujian Party History Monthly, 2012, (12): 65-71

[3] Liu Yubiao, Ma Jing. Thinking on the Red Culture Promoting the Localization of Marxism in China [J], Journal of Jinggangshan University (Social Science Edition), 2012, (3): 45-56

[4] Ma Jing. The Red Culture: the Culture Foundation for the Localization of Marxism in China [J], Journal of Southwest University of Political Science and Law, 2012, (1): 55-63

[5] Wen Yuepeng. Analysis on the Function of the Red Culture in Baise in Promoting the Popularization of the Marxism [J], Journal of Guangxi Youth Leaders College, 2012, (2): 60-71 